\title{
Corynebacterium mucifaciens sp. nov., an Unusual Species from Human Clinical Material
}

\author{
GUIDO FUNKE, ${ }^{1 *}$ PAUL A. LAWSON, ${ }^{2}$ AND MATTHEW D. COLLINS ${ }^{2}$ \\ Department of Medical Microbiology, University of Zürich, CH-8028 Zürich, Switzerland, ${ }^{1}$ and Department of \\ Microbiology, BBSRC Institute of Food Research, Reading RG6 6BZ, United Kingdom ${ }^{2}$
}

\begin{abstract}
Eight strains of a previously undescribed coryneform bacterium had been isolated from human clinical material over a 5-year period. Colonies of the unknown coryneform bacterium had an unusual appearance as they were slightly yellowish and very mucoid. Biochemical and chemotaxonomic characterization revealed that the unknown coryneform bacterium belonged to the genus Corynebacterium. It could be readily differentiated from all previously described Corynebacterium species. Electron microscopy demonstrated the production of an extracellular substance causing connecting filaments between cells as a morphological correlate to the mucoid colonies. Comparative 16S rRNA gene sequence analysis revealed that the unknown coryneform bacterium represented a new subline within the genus Corynebacterium, for which the name Corynebacterium mucifaciens sp. nov. is proposed. The type strain is CCUG 36878 (= DSM $44265=$ CIP 105129).
\end{abstract}

The genus Corynebacterium is the largest genus in the coryneform group of bacteria (i.e., aerobically growing, asporogenous, non-partially acid-fast, irregular gram-positive rods) and currently comprises more than 25 species (11). During the past decade, 12 new Corynebacterium species have been established $(9,11)$. Interestingly, all of these were derived from human clinical specimens, whereas only 7 of the 17 Corynebacterium species listed in Bergey's Manual of Systematic Bacteriology are considered medically relevant $(4,11)$. The present report deals with yet another novel Corynebacterium species isolated from human clinical specimens. Over a 5-year period, eight strains of a coryneform bacterium whose colonies were slightly yellowish and markedly mucoid were isolated from human clinical material. In a polyphasic approach including both phenotypic and molecular genetic methods, it was demonstrated that this coryneform bacterium represents a new Corynebacterium species, for which the name Corynebacterium mucifaciens sp. nov. is proposed.

\section{MATERIALS AND METHODS}

Bacterial strains. The origins of the strains studied and their clinical sources are given in Table 1. Four strains were isolated by workers at the Department of Medical Microbiology, University of Zürich, Zürich, Switzerland, and four other isolates were received by the reference laboratory for coryneform bacteria of the same institution.

Phenotypic characteristics. Strains were grown aerobically at $37^{\circ} \mathrm{C}$ in a $5 \%$ $\mathrm{CO}_{2}$-enriched atmosphere on Columbia agar (Difco, Detroit, Mich.) supplemented with $5 \%$ sheep blood. The methods used for biochemical profiling of the bacteria have been outlined in detail previously (8). By using the API Coryne system (bioMérieux, Marcy l'Etoile, France), enzymatic reactions were determined after $24 \mathrm{~h}$ at $37^{\circ} \mathrm{C}$, and acid production from carbohydrates was observed after $48 \mathrm{~h}$ of incubation. The API $50 \mathrm{CH}$ system (acid production from additional carbohydrates) was used in conjunction with $50 \mathrm{CHE}$ medium (both from bioMérieux), and reactions were read after $96 \mathrm{~h}$ of incubation at $37^{\circ} \mathrm{C}$.

Electron microscopy. Cells were grown in brain heart infusion broth (Becton Dickinson. Cockeysville, Md.) for $18 \mathrm{~h}$ at $37^{\circ} \mathrm{C}$, harvested by centrifugation, and washed three times with $0.9 \% \mathrm{NaCl}$. Pelleted cells were fixed for $60 \mathrm{~min}$ at $4^{\circ} \mathrm{C}$

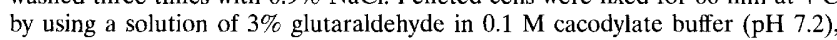
washed with phosphate-buffered saline, and postfixed for 30 min with $2 \%$ osmium tetroxide in cacodylate buffer. After two additional washes in water, the fixed pellets were incubated in a $2 \%$ uranyl acetate solution overnight. Cells were then dehydrated in 2,2-dimethoxypropane and embedded in epon-araldite. Thin

* Corresponding author. Mailing address: Department of Medical Microbiology, University of Zürich, Gloriastrasse 32, CH-8028 Zürich, Switzerland. Phone: 41-1-634-2700. Fax: 41-1-634-4906. E-mail: funke @immv.unizh.ch. sections were contrasted with lead citrate and examined with a Philips model EM400 transmission electron microscope.

Chemotaxonomic investigations. The methods used for analyses of cellular fatty acids (gas-liquid chromatography [25]), cell wall diamino acids (thin-layer chromatography [8]), mycolic acids (thin-layer chromatography [8]), the acyl type of the muramic acid (tube test [23]), and the $\mathrm{G}+\mathrm{C}$ content (high-performance liquid chromatography [7]) have been described previously.

Antimicrobial susceptibility testing. MICs of 26 antimicrobial agents were determined by a microdilution method (Merlin Diagnostics, Bornheim-Hersel, Germany) as outlined previously (7). The results were interpreted by using National Committee for Clinical Laboratory Standards breakpoints (19).

Determination of the 16S rRNA gene sequences and phylogenetic analyses. $A$ large fragment of the $16 \mathrm{~S}$ rRNA gene was amplified by PCR by using universal primers $\mathrm{pA}$ and $\mathrm{pH}^{*}$ as previously described (15). The PCR products were purified by using a Prep-A-Gene kit (Bio-Rad, Hercules, Calif.) and were sequenced by using a Taq DyeDeoxy terminator cycle sequencing kit (Applied Biosystems, Foster City, Calif.) and a model 373A automatic sequencer (Applied Biosystems). Searches in the EMBL/GenBank Data Library were performed with the program FASTA in order to establish the relatives of the clinical strains. Sequences of the close relatives were retrieved and aligned with the newly determined sequences by using the program PILEUP (5). The rRNA alignment was corrected manually, and approximately 100 bases at the $5^{\prime}$ end of the molecule were omitted from further analyses because of alignment uncertainties due to highly variable region V1. Levels of sequence similarity were calculated and corrected for substitution rates by using Kimura's parameters. A phylogenetic tree was constructed by the neighbor-joining method (22), and the stability of relationships was assessed by using the programs SEQBOOT, DNADIST NEIGHBOR, and CONSENSE of the PHYLIP package (6).

Nucleotide sequence accession number. The $16 \mathrm{~S}$ rRNA gene sequence of strain DMMZ $2278^{\mathrm{T}}\left(=\right.$ CCUG $36878^{\mathrm{T}}=$ DSM $44265^{\mathrm{T}}=$ CIP $105129^{\mathrm{T}}$ ) has been deposited in the EMBL Data Library under accession no. Y11200.

\section{RESULTS AND DISCUSSION}

Six of the eight clinical strains were isolated from blood cultures (Table 1). The remaining strains originated from a wound swab and joint fluid. All eight strains grew in pure culture from clinical specimens. The patients from whom the isolates were recovered were epidemiologically not linked.

Colonies of the strains were 1 to $1.5 \mathrm{~mm}$ in diameter after $24 \mathrm{~h}$ of incubation at $37^{\circ} \mathrm{C}$ in a $5 \% \mathrm{CO}_{2}$-enriched atmosphere. They were glistening, slightly yellowish, and very mucoid. A slimy consistency was also observed when colonies were subcultured for further testing, but colonies appeared to be less mucoid after $96 \mathrm{~h}$ of incubation. Initially, the mucoid colony appearance of the unknown bacterium somewhat resembled the appearance of Rhodococcus equi colonies (13). However, we did not observe a rod-coccus cycle (as seen in $R$. equi strains [13]) in the unknown bacteria when cells were grown on suitable media. Gram staining revealed typical diphtheroids which were 
TABLE 1. Stains included in the present study

\begin{tabular}{lclccl}
\hline \multicolumn{1}{c}{ Strain $^{a}$} & $\begin{array}{c}\text { Year of } \\
\text { isolation }\end{array}$ & \multicolumn{1}{c}{ City of isolation } & $\begin{array}{c}\text { Sex of } \\
\text { patient }\end{array}$ & $\begin{array}{c}\text { Age of } \\
\text { patient (yr) }\end{array}$ & Source (clinical diagnosis or procedure) \\
\hline DMMZ 216 & 1992 & Zürich, Switzerland & M & 49 & Blood culture (intestinal bleeding) \\
DMMZ 300 & 1992 & Zürich, Switzerland & M & 24 & Joint fluid (arthritis) \\
DMMZ 341 & 1993 & Lausanne, Switzerland & M & 23 & Wound swab (cat bite) \\
DMMZ 394 & 1993 & Zürich, Switzerland & F & 32 & Blood culture (fever of unknown origin) \\
DMMZ 418 & 1993 & Basel, Switzerland & M & 58 & Blood culture (not known) \\
DMMZ 1348 & 1995 & Bern, Switzerland & M & 45 & Blood culture (fever of unknown origin) \\
DMMZ 2125 & 1996 & Leipzig, Germany & F & 45 & Blood culture (human immunodeficiency \\
virus infection) & Blood culture (cardiac surgery) \\
\hline
\end{tabular}

${ }^{a}$ DMMZ, Department of Medical Microbiology, University of Zürich.

${ }^{b} \mathrm{M}$, male; F, female.

occasionally club shaped, as seen only in true Corynebacterium spp. (11). The eight strains examined were not partially acid fast.

In order to visualize a possible mucus layer as the morphological correlate of the bacterial colony appearance, electron microscopy of ultrathin cross sections of the cells was performed. As seen in Fig. 1, fine to broad electron-opaque filaments connected adjacent cells. A very similar pattern is observed in $R$. equi (12). Otherwise, extracellular slime-producing Corynebacterium spp. are very rarely found (2). The chemical structure of the filaments connecting the coryneform bacteria is not known at present, but it is not unlikely that the filaments are composed of polysaccharides which may represent a virulence factor, as demonstrated in $R$. equi (16).

The following initial phenotypic screening characteristics of coryneform bacteria (24) were observed: cells were catalase positive, nonfermenting, nonmotile, nitrate reduction negative, and urea and esculin hydrolysis negative; acid was produced from glucose but not from maltose, mannitol, and xylose, and three of the eight strains produced acid from sucrose; the strains were nonlipophilic; and the CAMP reaction was negative. The API Coryne system gave the numerical codes $2100104(n=2), 2100105(n=1), 6100104(n=3)$, and $6100105(n=2)$, which corresponded according to the system's database with identification of the isolates as the lipophilic taxa Corynebacterium jeikeium, Corynebacterium bovis, and CDC group $\mathrm{G}$ or the nonlipophilic, fermenting species Corynebacterium striatum (1). However, as revealed by the initial phenotypic screening reactions of the unknown coryneform bacteria, it was obvious that they did not belong to any of these taxa since they were nonlipophilic and nonfermenting. They could be readily distinguished from other nonfermenting corynebacteria (Table 2). Further testing of enzymatic reactions with the API ZYM system revealed esterase, esterase-lipase, cystine arylamidase, and acid phosphatase activities but not valine arylamidase, $\alpha$-glucosidase, and $\beta$-glucosidase activities, all of which are detected in $R$. equi strains (18). In addition, the unknown coryneform bacteria produced acid from glycerol, fructose, and mannose, characteristics which are not observed in $R$, equi strains (17).

In all eight clinical strains, $\mathrm{C}_{16: 0}(42 \% \pm 3 \%$ [mean \pm standard deviation]), $C_{18: 1 \omega 9 \text { cis }}(40 \% \pm 4 \%)$, and $C_{18: 0}(11 \% \pm$ $3 \%$ ) were the predominant cellular fatty acids (CFAs), which was compatible with assignment to the genus Corynebacterium $(3,25)$. Significantly, in all of the strains tuberculostearic acid accounted for only 1 to $2 \%$ of the total CFAs. Tuberculostearic acid is very rarely found in nonlipophilic Corynebacterium spp. $(3,25)$. In contrast, $R$. equi strains contain much larger amounts of tuberculostearic acid, up to $22 \%$ of their total CFAs (25). Cell wall analysis revealed the presence of meso- diaminopimelic acid as the diamino acid, as well as the presence of short-chain mycolic acids. Furthermore, the acyl type of the muramic acid of the eight strains studied was the acetyl type, as in Corynebacterium spp., and not the glycolyl type, as in Rhodococcus spp. (14). The $\mathrm{G}+\mathrm{C}$ content was found to range from 63 to $65 \mathrm{~mol} \%$. All chemotaxonomic features, thus, were compatible only with assignment of the eight strains studied to the genus Corynebacterium (4).

The antimicrobial susceptibility patterns were similar for many of the isolates when the categories for susceptibility and resistance were applied. It was observed that the aminoglycosides amikacin (MIC at which $50 \%$ of the isolates were inhibited $\left[\mathrm{MIC}_{50}\right.$ ], $0.25 \mu \mathrm{g} / \mathrm{ml} ; \mathrm{MIC}$ range, $\leq 0.125$ to $0.5 \mu \mathrm{g} / \mathrm{ml}$ ), gentamicin $\left(\mathrm{MIC}_{50}, \leq 0.063 \mu \mathrm{g} / \mathrm{ml}\right.$; MIC range, $\leq 0.063$ to 2 $\mu \mathrm{g} / \mathrm{ml}$ ), netilmicin $\left(\mathrm{MIC}_{50}, \leq 0.063 \mu \mathrm{g} / \mathrm{ml}\right.$; MIC range, $\leq 0.063$ $\mu \mathrm{g} / \mathrm{ml}$ ), and tobramycin ( $\mathrm{MIC}_{50}, 0.125 \mu \mathrm{g} / \mathrm{ml}$; MIC range, $\leq 0.063$ to $0.25 \mu \mathrm{g} / \mathrm{ml}$ ) exhibited good activity against the unknown Corynebacterium strains. In contrast, the tetracyclines doxycycline $\left(\mathrm{MIC}_{50}, 4 \mu \mathrm{g} / \mathrm{ml}\right.$; MIC range, 2 to $\left.16 \mu \mathrm{g} / \mathrm{ml}\right)$, minocycline $\left(\mathrm{MIC}_{50}, 4 \mu \mathrm{g} / \mathrm{ml}\right.$; MIC range, 2 to $\left.16 \mu \mathrm{g} / \mathrm{ml}\right)$, and tetracycline $\left(\mathrm{MIC}_{50}, 32 \mu \mathrm{g} / \mathrm{ml}\right.$; MIC range, 4 to $\left.64 \mu \mathrm{g} / \mathrm{ml}\right)$ were only poorly active against most of the strains tested. Resistance to the macrolides azithromycin $\left(\mathrm{MIC}_{50},>64 \mu \mathrm{g} / \mathrm{ml}\right.$; MIC range, $\leq 0.032$ to $>64 \mu \mathrm{g} / \mathrm{ml}$ ), clarithromycin $\left(\mathrm{MIC}_{50}, 2 \mu \mathrm{g} / \mathrm{ml}\right.$; $\mathrm{MIC}$ range, $\leq 0.032$ to $8 \mu \mathrm{g} / \mathrm{ml}$ ), and erythromycin $\left(\mathrm{MIC}_{50}\right.$, $\geq 64 \mu \mathrm{g} / \mathrm{ml} ;$ MIC range, $\leq 0.032$ to $>64 \mu \mathrm{g} / \mathrm{ml}$ ) was observed in five of the eight strains, and the MIC of clarithromycin was consistently lower than the MICs of the other macrolides. Resistance to clindamycin $\left(\mathrm{MIC}_{50},>32 \mu \mathrm{g} / \mathrm{ml}\right.$; MIC range, 0.25 to $>32 \mu \mathrm{g} / \mathrm{ml}$ ) was always combined with macrolide resistance, suggesting that an rRNA methylase was present, as has been observed in other coryneform bacteria (10). The MICs of chloramphenicol $\left(\mathrm{MIC}_{50}, 8 \mu \mathrm{g} / \mathrm{ml}\right.$; MIC range, 4 to $128 \mu \mathrm{g} / \mathrm{ml}$ ) were elevated for strains DMMZ 216 (MIC, 64 $\mu \mathrm{g} / \mathrm{ml}$ ) and DMMZ 418 (MIC, $128 \mu \mathrm{g} / \mathrm{ml}$ ). Strains DMMZ 394 and DMMZ 2125 had slightly elevated penem MICs (e.g., the MIC of imipenem was $2 \mu \mathrm{g} / \mathrm{ml}$ ), whereas for the other six strains the MICs of penems ranged from $\leq 0.032$ to $0.06 \mu \mathrm{g} / \mathrm{ml}$. Strain DMMZ 2125 was multiresistant since it was also resistant to rifampin (MIC, $>32 \mu \mathrm{g} / \mathrm{ml}$ ) and quinolones (e.g., the MIC for ciprofloxacin was $16 \mu \mathrm{g} / \mathrm{ml}$ ) and exhibited elevated MICs with all $\beta$-lactams. Otherwise, the MICs of $\beta$-lactams for the other seven strains were below the susceptible breakpoints; e.g., the $\mathrm{MIC}_{50}$ of cefazolin was $\leq 0.125 \mu \mathrm{g} / \mathrm{ml}$ (MIC range, $\leq 0.125 \mu \mathrm{g} / \mathrm{ml}$ ), and the $\mathrm{MIC}_{50}$ of penicillin $\mathrm{G}$ was $0.25 \mu \mathrm{g} / \mathrm{ml}$ (MIC range, 0.125 to $1 \mu \mathrm{g} / \mathrm{ml})$. Fusidic acid $\left(\mathrm{MIC}_{50}, 0.25\right.$ $\mu \mathrm{g} / \mathrm{ml}$; MIC range, 0.125 to $0.5 \mu \mathrm{g} / \mathrm{ml}$ ), as well as the glycopeptides teicoplanin $\left(\mathrm{MIC}_{50}, 0.5 \mu \mathrm{g} / \mathrm{ml}\right.$; MIC range, 0.25 to 0.5 $\mu \mathrm{g} / \mathrm{ml}$ ) and vancomycin $\left(\mathrm{MIC}_{50}, 0.5 \mu \mathrm{g} / \mathrm{ml}\right.$; MIC range, 0.5 


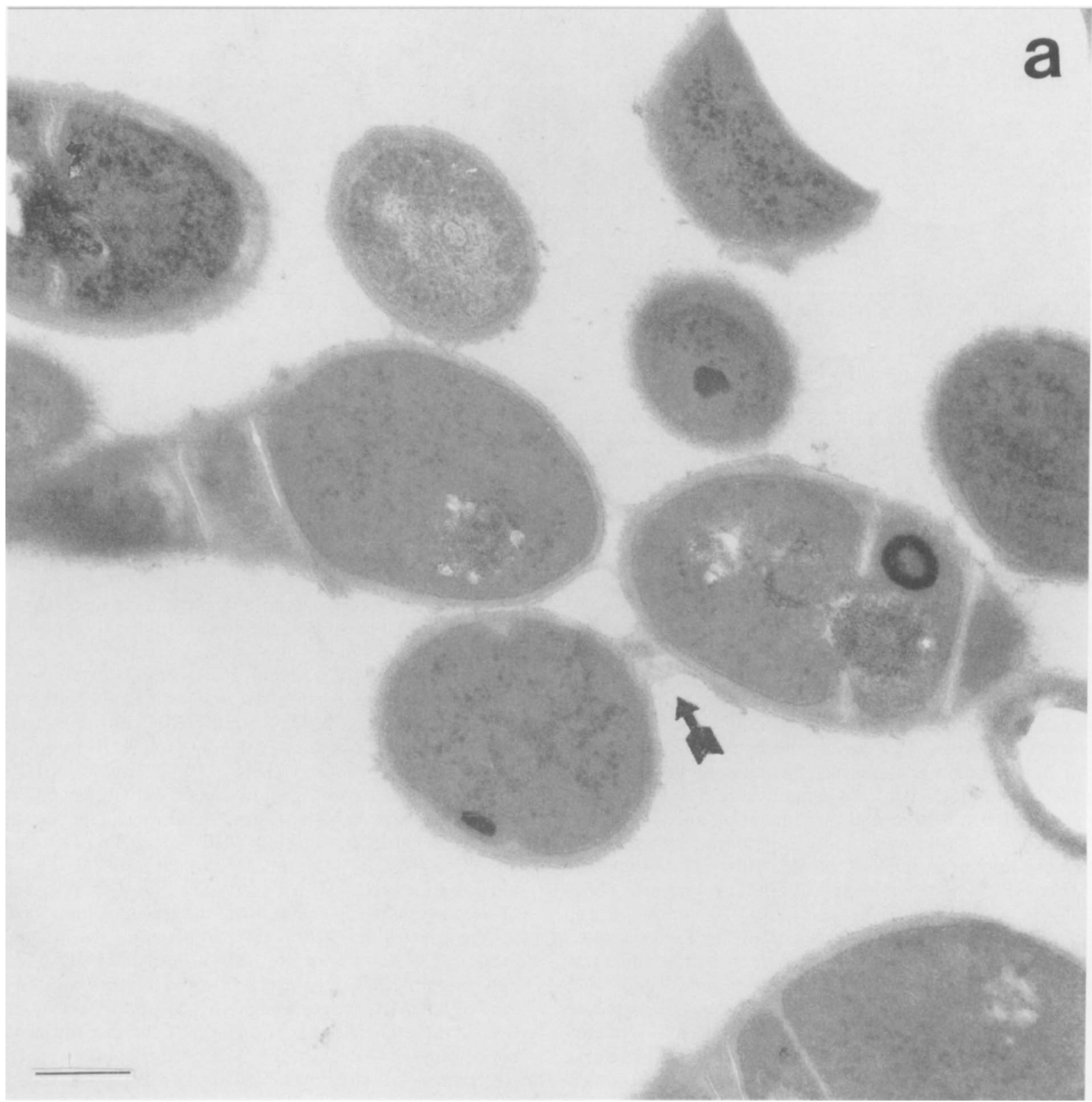

FIG. 1. Thin sections of $C$. mucifaciens. Note the extracellular material and the connecting filaments between the cells (arrows). Bars $=0.2 \mu \mathrm{m}$.

$\mu \mathrm{g} / \mathrm{ml}$ ), showed good activity against the eight isolates tested, whereas all eight isolates were resistant to aztreonam $\left(\mathrm{MIC}_{50}\right.$, $>64 \mu \mathrm{g} / \mathrm{ml}$; MIC range, $>64 \mu \mathrm{g} / \mathrm{ml})$, cefetamet $\left(\mathrm{MIC}_{50},>64\right.$ $\mu \mathrm{g} / \mathrm{ml} ;$ MIC range, $>64 \mu \mathrm{g} / \mathrm{ml})$, ceftibuten $\left(\mathrm{MIC}_{50},>64 \mu \mathrm{g} / \mathrm{ml}\right.$; MIC range, $>64 \mu \mathrm{g} / \mathrm{ml}$ ), and fosfomycin ( $\mathrm{MIC}_{50},>256 \mu \mathrm{g} / \mathrm{ml}$; MIC range, $>256 \mu \mathrm{g} / \mathrm{ml}$ ).

In order to determine the phylogenetic position and the genealogical distinctiveness of the unknown Corynebacterium strains, the genes encoding the 16S rRNA of strains DMMZ 300, DMMZ 394, DMMZ 1348, and DMMZ 2278 ${ }^{\mathrm{T}}$ were amplified by PCR and subjected to sequence analysis. The almost complete 16S rRNA gene sequence $(1,459$ nucleotides) of strain DMMZ $2278^{\mathrm{T}}$ was determined. Comparative sequence analysis revealed that strain DMMZ $2278^{\mathrm{T}}$ was a member of the actinomycete high-G+C-content subphylum of gram-positive bacteria and displayed the highest sequence similarities
(>92\%) with species of the genus Corynebacterium (Table 2). Significantly lower levels of relatedness were found with other actinomycete and coryneform taxa (data not shown). A tree depicting the phylogenetic relationships of the unidentified bacterium within the genus Corynebacterium is shown in Fig. 2. The new bacterium showed a close (approximately 1.5\% 16S rRNA divergence) and statistically significant (bootstrap value, 90) phylogenetic affinity to Corynebacterium afermentans (both subspecies), and Corynebacterium coyleae was the next nearest relative (Fig. 2). Partial 16S rRNA sequence analyses (approximately 800 nucleotides, including variable regions V1 to V3) conducted with three other strains of the unidentified bacterium revealed $100 \%$ sequence similarity between isolates, thereby demonstrating the genealogical homogeneity of these organisms.

It is evident from both sequence divergence values and the 


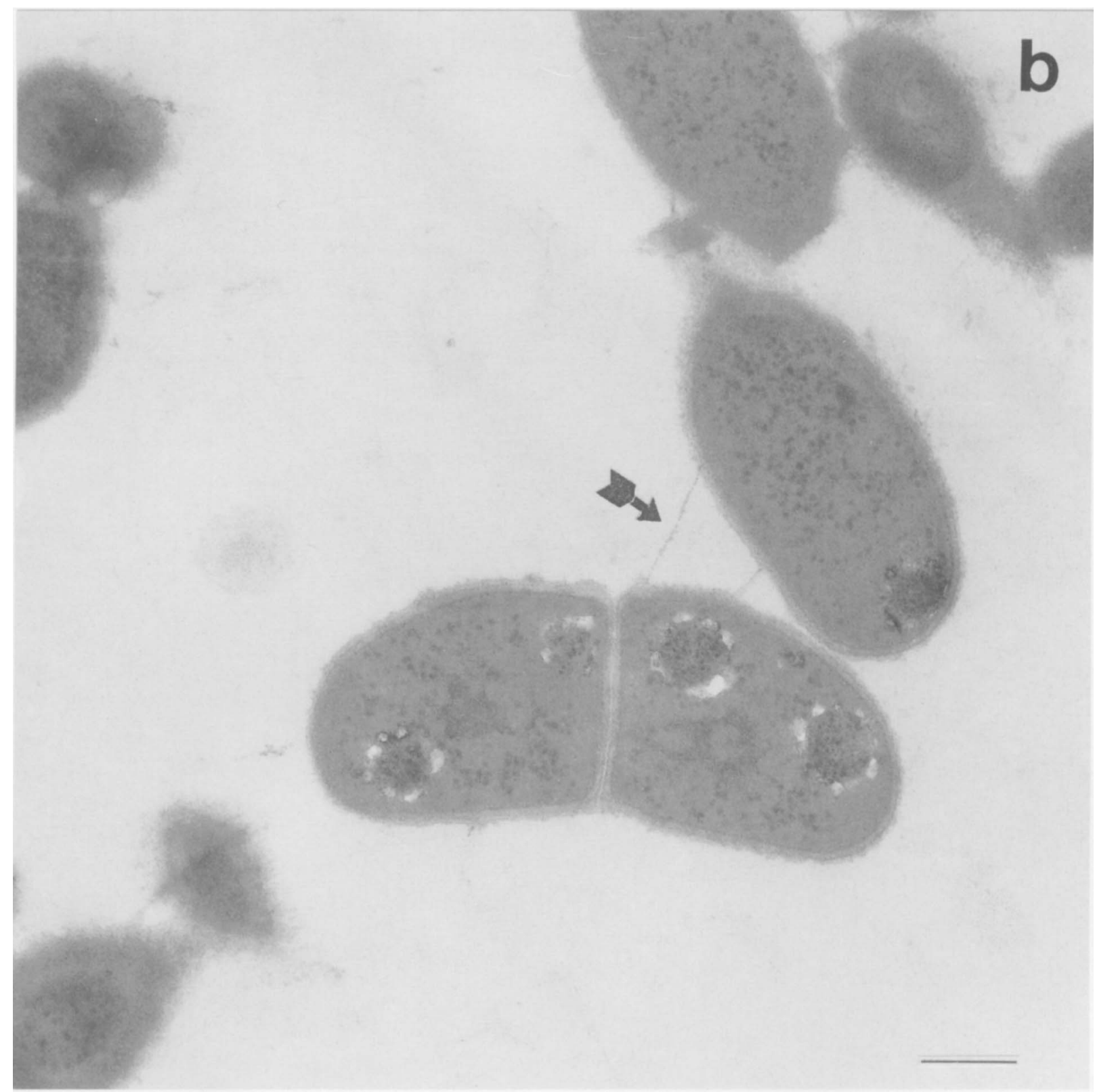

FIG. 1-Continued

TABLE 2. Characteristics that differentiate $C$. mucifaciens from other nonfermenting Conynebacterium spp. ${ }^{a}$

\begin{tabular}{|c|c|c|c|c|c|c|c|c|c|c|c|}
\hline \multirow{2}{*}{ Organism } & \multirow{2}{*}{ Lipophilia } & \multirow{2}{*}{$\begin{array}{l}\text { Nitrate } \\
\text { reduction }\end{array}$} & \multirow{2}{*}{$\begin{array}{c}\text { Urea } \\
\text { hydrolysis }\end{array}$} & \multirow{2}{*}{$\begin{array}{l}\text { Esculin } \\
\text { hydrolysis }\end{array}$} & \multirow{2}{*}{$\begin{array}{l}\text { Pyrazin- } \\
\text { amidase }\end{array}$} & \multirow{2}{*}{$\begin{array}{l}\text { Alkaline } \\
\text { phosphatase }\end{array}$} & \multicolumn{3}{|c|}{ Acid produced from: } & \multirow{2}{*}{$\begin{array}{l}\text { CAMP } \\
\text { reaction }\end{array}$} & \multirow{2}{*}{ Other traits } \\
\hline & & & & & & & Glucose & Maltose & Sucrose & & \\
\hline C. mucifaciens & $-b$ & - & - & - & + & + & + & - & V & - & $\begin{array}{l}\text { Slightly yellowish, } \\
\text { mucoid colonies }\end{array}$ \\
\hline $\begin{array}{l}\text { C. afermentans subsp. } \\
\text { afermentans }\end{array}$ & - & - & - & - & + & + & - & - & - & V & \\
\hline $\begin{array}{l}\text { C. afermentans subsp. } \\
\text { lipophilum }\end{array}$ & + & - & - & - & + & + & - & - & - & - & \\
\hline C. auris & - & - & - & - & + & + & - & - & - & + & $\begin{array}{l}\text { Cleaved mycolic } \\
\text { acids }\end{array}$ \\
\hline C. jeikeium & + & - & - & - & + & + & + & V & - & - & \\
\hline C. propinquum & - & + & - & - & $\mathrm{V}$ & $\mathrm{V}$ & _- & - & - & - & Tyrosine positive \\
\hline C. pseudodiphtheriticum & - & + & + & - & + & $\mathrm{V}$ & - & - & - & - & \\
\hline C. urealyticum & + & - & + & - & + & $\mathrm{V}$ & - & - & - & - & \\
\hline
\end{tabular}

${ }^{a}$ Data from references 1 and 11.

${ }^{b}-$, negative; +, positive; $\mathrm{V}$, variable. 


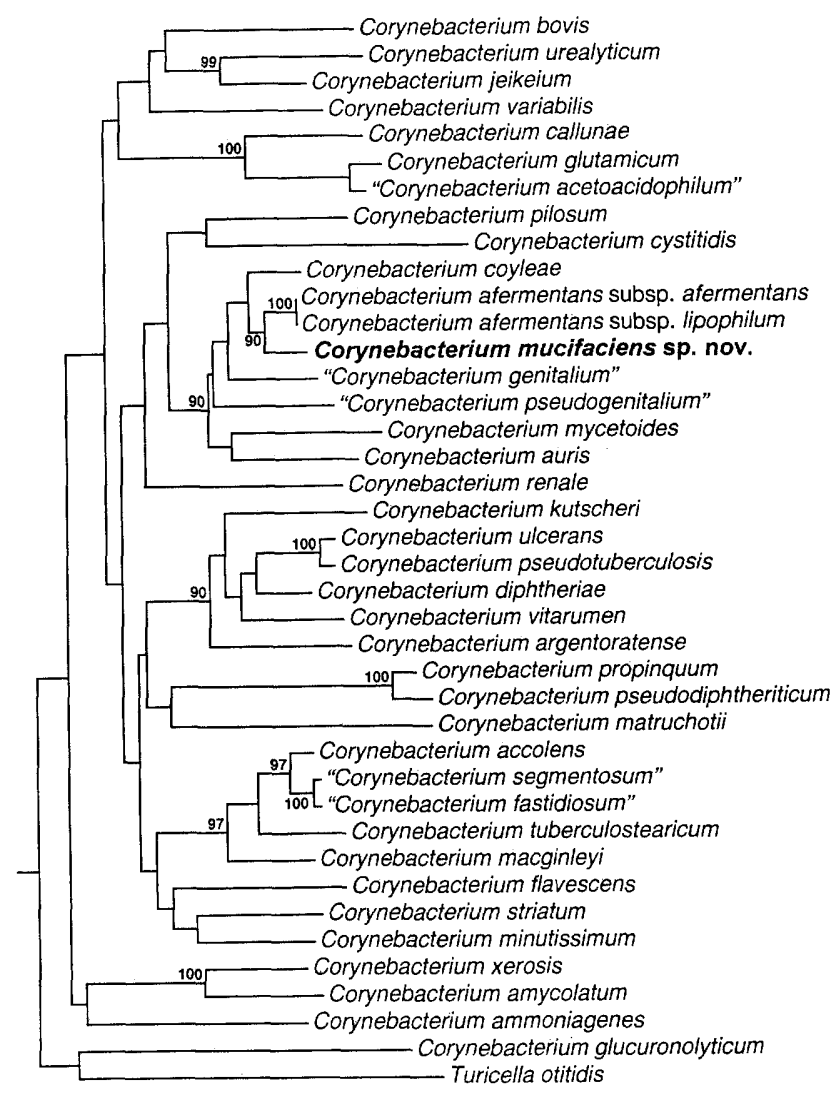

FIG. 2. Unrooted tree showing the phylogenetic relationships of C. mucifaciens sp. nov. and other members of the genus Corynebacterium. The tree, constructed by using the neighbor-joining method, was based on a comparison of approximately 1,320 nucleotides. Bootstrap values, expressed as percentages of 500 replications, are given at the branch points.

treeing analysis that the closest phylogenetic relatives of the unknown Corynebacterium strains are C. afermentans (approximately $98.5 \%$ 16S rRNA similarity) and $C$. coyleae (approximately $97.7 \% 16 \mathrm{~S}$ rRNA similarity) (Table 3). Although it is not possible to derive precise $16 \mathrm{~S}$ rRNA sequence divergence values for delineating new species, the $1.5 \%$ 16S rRNA divergence between the unknown Corynebacterium sp. and its closest neighbors, together with the distinctive phenotype of the unknown Corynebacterium sp., clearly demonstrates that it represents a new species. It is important to note that within the genus Corynebacterium many genomically distinct species, including Corynebacterium pseudodiphtheriticum and Corynebacterium propinquum ( $>99 \%$ 16S rRNA similarity), Corynebacterium diphtheriae, Corynebacterium ulcerans, and Corynebacterium pseudotuberculosis ( $>98 \%$ 16S rRNA similarity), and CDC coryneform group $\mathrm{G}$ bacteria and Corynebacterium accolens (>98\% 16S rRNA similarity) $(20,21)$, exhibit comparable or even higher levels of relatedness. Therefore, based on the results of phenotypic and molecular genetic studies, we propose that the unknown coryneform bacteria described above should be classified as members of a new species of the genus Corynebacterium, for which we propose the name Corynebacterium mucifaciens sp. nov. This species can be readily differentiated from other nonfermenting members of the genus Corynebacterium (Table 2).

Description of Corynebacterium mucifaciens sp. nov. Corynebacterium mucifaciens (mu.ci.fa'ci.ens. L. n. mucus, slime; L.
TABLE 3. Levels of 16S rRNA sequence similarity between C. mucifaciens sp. nov. and other Corynebacterium species and subspecies

Species or subspecies

$(\text { EMBL accession no. })^{a}$

$\% 16 \mathrm{~S}$ rRNA

sequence similarity with $C$. mucifaciens sp. nov.

C. accolens (X80500).......................................................... 95.2

"C. acetoacidophilum" (X84240) ......................................... 94.1

C. afermentans subsp. afermentans (X81874) ....................... 98.5

C. afermentans subsp. lipophilum (X80255) ......................... 98.5

C. ammoniagenes (X84440) ................................................... 93.6

C. amycolatum (X84244) …………….................................. 94.2

C. argentoratense (X83955) ..................................................... 94.6

C. auris (X82493) .................................................................. 95.7

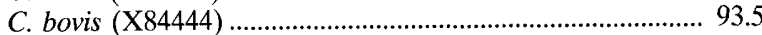

C. callunae (X84251) ........................................................ 93.9

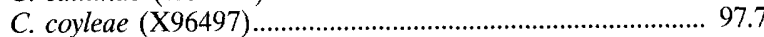

C. cystitidis (X84252)............................................................ 94.2

C. diphtheriae (X84248) ....................................................... 95.7

"C. fastidiosum" (X84245) …………….................................... 95.1

C. flavescens (X84441) ............................................................ 94.4

"C. genitalium" (X84253).......................................................... 96.9

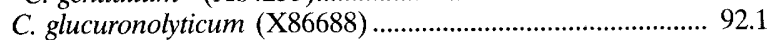

C. glutamicum (X84257) ....................................................... 93.6

C. jeikeium (X84250)........................................................... 94.4

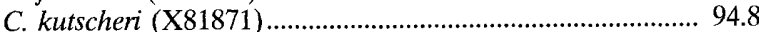

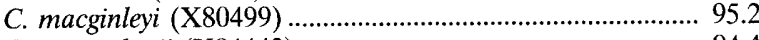

C. matruchotii (X84443) .......................................................... 94.4

C. minutissimum (X84678) ......................................................... 94.7

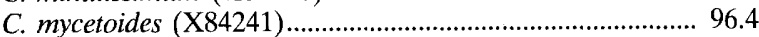

C. pilosum (X84246)................................................................ 94.3

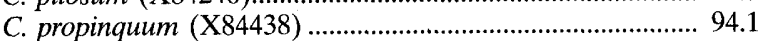

C. pseudodiphtheriticum (X84258) .......................................... 93.9

"C. pseudogenitalium" (X81874) ............................................... 96.1

C. pseudotuberculosis (X84255)............................................... 95.0

C. renale (X84249)............................................................... 94.8

"C. segmentosum" (X84437)..................................................... 95.0

C. striatum (X84442) .......................................................... 95.1

"C. tuberculostearicum" (X84247)........................................... 94.8

C. ulcerans (X84256) ............................................................... 95.2

C. urealyticum (X84439) ....................................................... 93.2

C. variabilis (X53185) ............................................................ 93.8

C. vitarumen (X84680) .............................................................. 95.2

C. xerosis (X84446) ................................................................. 92.9

${ }^{a}$ The numbers in parentheses are EMBL 16S rRNA nucleotide sequence accession numbers.

part. adj. faciens, producing; L. part. adj. mucifaciens, slime producing). The characteristics given below are based on the results of studies of eight strains.

Cells are gram positive and nonmotile and do not form spores. Colonies are circular, convex, glistening, slightly yellowish, and mucoid. Colony diameters are about 1 to $1.5 \mathrm{~mm}$ after $24 \mathrm{~h}$ of incubation on sheep blood agar at $37^{\circ} \mathrm{C}$. Catalase positive. Acid is produced from glycerol, glucose, fructose, and mannose but not from erythritol, arabinose, xylose, adonitol, $\beta$-methyl-xyloside, galactose, L-sorbose, rhamnose, dulcitol, inositol, mannitol, sorbitol, $\alpha$-methyl-D-mannoside, $\alpha$-methylD-glucoside, $N$-acetylglucosamine, amygdalin, arbutin, salicin, maltose, lactose, melibiose, trehalose, melezitose, D-raffinose, glycogen, $\beta$-gentiobiose, D-turanose, D-lyxose, D-tagatose, fucose, arabitol, gluconate, and 2-ketogluconate. Acid production from ribose and sucrose is variable. Nitrate is not reduced. Urea and esculin are not hydrolyzed. Not lipophilic. CAMP reaction negative. Pyrazinamidase, alkaline phosphatase, esterase, esterase-lipase, cystine arylamidase, and acid phosphatase are positive, whereas pyrrolidonyl arylamidase and phos- 
phoamidase are variable. Lipase, valine arylamidase, trypsin, chymotrypsin, $\alpha$-galactosidase, $\beta$-galactosidase, $\beta$-glucuronidase, $\alpha$-glucosidase, $\beta$-glucosidase, $N$-acetyl- $\beta$-glucosaminidase, $\alpha$-mannosidase, and $\alpha$-fucosidase activities are not detected.

The cell wall contains meso-diaminopimelic acid. Mycolic acids are present. The main straight-chain saturated fatty acids are palmitic and stearic acids; oleic acid is the predominant unsaturated fatty acid. The DNA base composition is 63 to 65 mol\% $\mathrm{G}+\mathrm{C}$. Isolated from human clinical specimens. Type strain DSM 2278 has been deposited in the Culture Collection of the University of Göteborg, Göteborg, Sweden, as CCUG 36878 , in the German Collection of Microorganisms and Cell Cultures, Braunschweig, Germany, as DSM 44265, and in the Culture Collection of the Institut Pasteur, Paris, France, as CIP 105129. Strain CCUG $36878^{\mathrm{T}}$ has the characteristics described above for the species, except that it is positive for pyrrolidonyl arylamidase, phosphoamidase, ribose, and sucrose reactions. Its $\mathrm{G}+\mathrm{C}$ content is $64 \mathrm{~mol} \%$.

\section{ACKNOWLEDGMENTS}

We thank R. Keller and T. Bächi for electron microscopy. A. von Graevenitz is acknowledged for a careful review of the manuscript.

This study was made possible by the financial support of European Union grant BIO2-CT943098, the Sassella-Stiftung, Zürich, the Jubiläumsspende der Universität Zürich, and the Hochschulverein der Universität Zürich. G.F. is a recipient of an ESCMID research fellowship.

\section{REFERENCES}

1. API System. 1989. API CORYNE analytical profile index, 1st ed. API System, La-Balme-les-Grottes, France.

2. Bayston, R., C. Compton, and K. Richards. 1994. Production of extracellular slime by coryneforms colonizing hydrocephalus shunts. J. Clin. Microbiol. 32:1705-1709.

3. Bernard, K. A., M. Bellefeuille, and E. P. Ewan. 1991. Cellular fatty acid composition as an adjunct to the identification of asporogenous, aerobic, gram-positive rods. J. Clin. Microbiol. 29:83-89.

4. Collins, M. D., and C. S. Cummins. 1986. Genus Conynebacterium, p. 12661276. In P. H. A. Sneath, N. S. Mair, M. E. Sharpe, and J. G. Holt (ed.), Bergey's manual of systematic bacteriology, vol. 2. The Williams \& Wilkins Co., Baltimore, Md.

5. Devereux, J., P. Haeberli, and D. Smithies. 1984. A comprehensive set of sequence analysis programmes for the VAX. Nucleic Acids Res. 12:387-395.

6. Felsenstein, J. 1989. PHYLIP-phylogeny inference package (version 3.2). Cladistics 5:164-166.

7. Funke, G., N. Alvarez, C. Pascual, E. Falsen, E. Akervall, L. Sabbe, L. Schouls, N. Weiss, and M. D. Collins. 1997. Actinomyces europaeus sp. nov., isolated from human clinical specimens. Int. J. Syst. Bacteriol. 47:687-692.
8. Funke, G., G. Martinetti Lucchini, G. E. Pfyffer, M. Marchiani, and A. von Graevenitz. 1993. Characteristics of CDC group 1 and group 1-like coryneform bacteria isolated from clinical specimens. J. Clin. Microbiol. 31:29072912.

9. Funke, G., C. Pascual Ramos, and M. D. Collins. 1997. Connebacterium coyleae sp. nov., isolated from human clinical specimens. Int. J. Syst. Bacteriol. 47:92-96.

10. Funke, G., V. Pünter, and A. von Graevenitz. 1996. Antimicrobial susceptibility patterns of some recently defined coryneform bacteria. Antimicrob. Agents Chemother. 40:2874-2878.

11. Funke, G., A. von Graevenitz, J. E. Clarridge III, and K. A. Bernard. 1997. Clinical microbiology of coryneform bacteria. Clin. Microbiol. Rev. 10:125159.

12. Garrison, R. G., F. K. Mirikitani, and J. W. Lane. 1983. Fine structural studies of Rhodococcus species. Microbios 36:183-190.

13. Goodfellow, M. 1986. Genus Rhodococcus, p. 1472-1481. In P. H. A. Sneath, N. S. Mair, M. E. Sharpe, and J. G. Holt (ed.), Bergey's manual of systematic bacteriology, vol. 2. The Williams \& Wilkins Co., Baltimore, Md.

14. Goodfellow, M. 1992. The family Nocardiaceae, p. 1188-1213. In A. Balows, H. G. Trüper, M. Dworkin, W. Harder, and K. H. Schleifer (ed.), The prokaryotes, vol. 2. Springer-Verlag, New York, N.Y.

15. Hutson, R. A., D. E. Thompson, and M. D. Collins. 1993. Genetic interrelationships of saccharolytic Clostridium botulinum types B, E and F and related clostridia as revealed by small-subunit rRNA gene sequences. FEMS Microbiol. Lett. 108:103-110.

16. Leitch, R. A., and J. C. Richards. 1990. Structural analysis of the specific capsular polysaccharide of Rhodococcus equi serotype 1. Biochem. Cell Biol. 68:778-789.

17. McNeil, M. M., and J. M. Brown. 1994. The medically important aerobic actinomycetes: epidemiology and microbiology. Clin. Microbiol. Rev. 7:357417.

18. Mutimer, M. D., and J. B. Woolcock. 1982. API ZYM for identification of Conynebacterium equi. Zentralbl. Bakteriol. Parasitenkd. Infektionskr. Hyg. Abt. 1 Orig. Reihe C 3:410-415.

19. National Committee for Clinical Laboratory Standards. 1997. Minimum inhibitory concentration (MIC) interpretive standards $(\mu \mathrm{g} / \mathrm{ml})$ for organisms other than Haemophilus spp., Neisseria gonorrhoeae, and Streptococcus spp. NCCLS document M7-A4. National Committee for Clinical Laboratory Standards, Wayne, $\mathrm{Pa}$.

20. Pascual, C., P. A. Lawson, J. A. E. Farrow, M. Navarro Gimenez, and M. D. Collins. 1995. Phylogenetic analysis of the genus Corynebacterium based on 16S rRNA gene sequences. Int. J. Syst. Bacteriol. 45:724-728.

21. Ruimy, R., P. Riegel, P. Boiron, H. Monteil, and R. Christen. 1995. Phylogeny of the genus Corynebacterium deduced from analyses of small-subunit ribosomal DNA sequences. Int. J. Syst. Bacteriol. 45:740-746.

22. Saitou, N., and M. Nei. 1987. The neighbor-joining method: a new method for reconstructing phylogenetic trees. Mol. Biol. Evol. 4:406-425.

23. Uchida, K., and K. Aida. 1984. An improved method for the glycolate test for simple identification of the acyl type of bacterial cell walls. J. Gen. Appl. Microbiol. 30:131-134.

24. von Graevenitz, A., and G. Funke. 1996. An identification scheme for rapidly and aerobically growing gram-positive rods. Zentralbl. Bakteriol. Parasitenkd. Infektionskr. Hyg. Abt. 1 Orig. 284:246-254.

25. von Graevenitz, A., G. Osterhout, and J. Dick. 1991. Grouping of some clinically relevant gram-positive rods by automated fatty acid analysis. APMIS 99:147154 